Buana Sains Vol 19 No 2 : 13 - 22, 2019

\title{
PENGARUH PEMBERIAN HORMON NAA, PUPUK GANDASIL DAN PUPUK GROWMORE PADA PERTUMBUHAN TANAMAN ANGGREK
}

\author{
Astri Sumiati dan Astutik
}

Fakultas Pertanian, Universitas Tribhuwana Tunggadewi

\begin{abstract}
Orchid is an ornamental plant, including the Orchidaceae tribe, which is widely favored among the ornamental plant community because it has high economic value, unique shapes, attractive colors and longer-lasting blooming flowers, one of which is a Phalaenopsis orchid. One of the efforts to accelerate the vegetative phalaenopsis can be done with the application of the NAA hormone and leaf fertilizers such as Gandasil fertilizer and Growmore fertilizer. The aims of this research to determine the effect of NAA, Gandasil and Growmore fertilizer types on the growth of hybrid Phalaenopsis orchids. The study was conducted at Greenhouse Jalan Tlogomas Kec. Lowokwaru, Malang City, for 5 months. The experiment was carried out using a factorial Completely Randomized Design (CRD) consisting of 2 factors namely, the factor I: NAA concentration: control 0 ppm (N0), 100 ppm (N1), 200 ppm (N2), and 300 ppm (N3). Factor II: leaf fertilizer, Growmore (P1) and Gandasil D (P2). Variables observed included: when buds appeared, leaf length, leaf width and percentage of live plants.

The results showed that there was an interaction between the concentration of NAA and the type of leaf fertilizer on the emergence of shoots. When the fastest shoots appear at $100 \mathrm{ppm}$ NAA, Growmore fertilizer (N1P1), which is 29 days. The NAA hormone influences the increase in leaf length and leaf width until 16 weeks of age. The best growth of hybrid Phalaenopsis was obtained at the administration of $200 \mathrm{ppm}$ NAA with an increase in leaf length of $1.49 \mathrm{~cm}$ and an increase in leaf width of $1.06 \mathrm{~cm}$ until 16 weeks of age. Growmore and Gandasil D did not affect the vegetative growth of hybrid Phalaenopsis Orchid plants.
\end{abstract}

Keywords: Gandasil fertilizer; Growmore fertilizer; NAA; Phalaenopsis; vegetative growth.

\section{Pendahuluan}

Anggrek merupakan tanaman hias termasuk suku Orchidaceae yang banyak digemari di kalangan komunitas tanaman hias dikarenakan memiliki nilai ekonomis tinggi, bentuk yang unik warna yang menarik dan daya tahan kemekaran bunga yang lebih lama, salah satunya adalah anggrek jenis Phalaenopsis (Hayuning et al., 2011). Volume ekspor anggrek di Indonesia masih relatif rendah bila dibandingkan dengan negara-negara lain seperti Thailand dan Singapura. Hal ini disebabkan masih rendahnya produksi bunga anggrek Indonesia, sedangkan jumlah permintaan di dalam mauppun luar negeri terus meningkat (Astuti, et al., 2012). Upaya dalam meningkatkan produksi dapat dilakukan berbagai budidaya dengan menggunakan zat pengatur tumbuh (ZPT) dan penggunan pupuk daun.

Kultur jaringan adalah suatu metode untuk mengisolasi bagian dari tanaman dan menumbuhkannya dalam kondisi aseptik, dengan demikian bagianbagian tersebut dapat memperbanyak 
diri dan beregenerasi menjadi tanaman lengkap kembali (Lisnandar et al., 2012). Tanaman atau plantlet yang tumbuh secara in vitro tanaman memerlukan tahap aklimatisasi, dalam aklimatisasi, media tanam menjadi salah satu faktor penentu keberhasilan dari setiap pertumbuhan anggrek karena media tumbuh sebagai tempat berpijak akar anggrek (Suradinata et al., 2012). Salah satu faktor yang berpengaruh pada pertumbuhan vegetatif anggrek adalah media tumbuh dan faktor lingkungan seperti cahaya, suhu, kelembaban dan kadar oksigen. Menurut Astutik (2006) media tumbuh berfungsi sebagai tempat mempertahankan kelembaban dan tempat penyimpanan hara dan air yang diperlukan mendukung pertumbuhan.

Zat pengatur tumbuh yang dihasilkan tanaman disebut fitohormon sedangkan yang sintetik disebut zat pengatur tumbuh tanaman sintetik (Lisnandar et al., 2012). Fungsi ZPT tersebut adalah untuk merangsang pertumbuhan morfogenesis dalam kultur sel, jaringan, dan organ. Salah satu jenis auksin sintetik yang sering digunakan adalah NAA (Naphthalene acetic acid) karena NAA mempunyai sifat lebih stabil dari pada IAA (Nisak et al., 2012). Penggunaan zat pengatur tumbuh bila digunakan dengan konsentrasi rendah akan merangsang dan mempercepat proses pertumbuhan tanaman, dan sebaliknya bila digunakan dalam jumlah besar/konsentrasi tinggi akan menghambat pertumbuhan bahkan dapat mematikan tanaman. Tanaman anggrek termasuk tanaman yang mempunyai kecepatan tumbuh yang cukup lambat. Kecepatan tumbuh ini cukup berpengaruh terhadap pemeliharaan tanaman anggrek. Oleh karena itu, budidaya perlu ditingkatkan untuk memacu kualitas dan kuantitas tanaman anggrek, salah satunya faktor jenis media dan pupuk yang digunakan (Nisak et al., 2012). Untuk memasok pertumbuhan anggrek Phalaenopsis dalam pot, salah satu caranya dapat dilakukan dengan pemberian pupuk daun, karena dalam pupuk daun sudah terdapat unsur hara yang dibutuhkan oleh tanaman anggrek, seperti pupuk daun Growmore. Unsur nitrogen berpengaruh meningkatkan pertumbuhan vegetatif, posfor berpengaruh untuk merangsang pertumbuhan generatif, inisiasi akar, dan pendewasaan tanaman, sedangkan kalium berfungsi sebagai katalisator (Ginting, 2008).

Berdasarkan penelitian Untari dan Puspitaningtyas (2006), melaporkan penggunaan medium VW yang ditambah dengan senyawa organik kompleks (air kelapa, pisang, kentang, ubi jalar, atau kedelai) dan NAA dapat menghasilkan 1.5-2 kali jumlah tunas pada anggrek. Jumlah rata-rata tunas yang terbentuk pada medium yang diperkaya ZPT sebanyak 12 dibandingkan pada kontrol yang hanya terbentuk 8 tunas. Hasil penelitian oleh Suradinata et al, (2012) media tanam campuran serat sabut kelapa dan arang kayu serta konsentrasi pupuk daun 2 g L-1 memberikan pengaruh paling baik terhadap pertambahan tinggi, lebar daun dan jumlah tunas tanaman anggrek Dendrobium sp. Berdasarkan uraian di atas perlu dilakukan penelitian tentang aplikasi NAA dan pupuk daun Growmore dan Gandasil D pada pertumbuhan vegetatif Phalaenopsis sp Hibrida. Penelitian bertujuan untuk mengetahui pengaruh NAA dan jenis pupuk daun terhadap pertumbuhan anggrek Phalaenopsis sp. 


\section{Metode Penelitian}

Penelitian dilaksanakan di Green house Jalan Tlogomas Kec. Lowokwaru, Kota Malang, selama 5 bulan. Alat yang digunakan dalam penelitian antara lain: kawat, tali raffiah, hand sprayer, gelas ukur, timbangan digital dan analitik, penggaris (mistar), kamera (HP), serta alat tulis. Bahan yang digunakan adalah: Phalaenopsis hibrida warna hijau siap diaklimatisasikan, hormon Naftalena Acetic Acide (NAA), pupuk daun Gandasil D dan Growmore, aquades dan tissue roll.

Penelitian dilakukan dengan menggunakan Rancangan Acak Kelompok (RAK) faktorial dengan 2 faktor. Faktor I : konsentrasi hormon Naftalena Acetic Acide (NAA) terdiri 4 level yakni : N0 : 0 ppm (kontrol), N2 : 200 ppm, N1: 100 ppm dan N3 : 300 ppm. Faktor II : pemberian pupuk daun, terdiri 2 variasi yaitu: P1 : pupuk daun Growmore $2 \mathrm{~g} / 1$ dan P2 : pupuk daun Gandasil D 2 g/l. Variabel pengamatan meliputi: saat muncul tunas, pertambahan jumlah daun, pertambahan panjang daun $(\mathrm{cm})$, pertambahan lebar daun $(\mathrm{cm})$, dan presentase tanaman hidup (\%).
Analisis Data menggunakanuji F, apabila hasil ragam berbeda nyata (F hitung $>\mathrm{F}$ tabel $5 \%$ ) atau berbeda sangat nyata ( $\mathrm{F}$ hitung $>\mathrm{F}$ tabel $1 \%$ ), maka dilakukan uji lanjutan dengan uji Beda Nyata Terkecil (BNT) taraf 5\%.

\section{Hasil dan Pembahasan}

\section{Saat Muncul Tunas (hari)}

Terdapat interaksi antara konsentrasi hormon NAA dengan jenis pupuk daun terhadap saat muncul tunas, dan secara terpisah konsentrasi hormon NAA tidak terdapat pengaruh pada saat muncul tunas, sedangkan jenis pupuk daun berpengaruh terhadap saat muncul tunas. (Tabel 1). Tabel 1 menunjukkan bahwa interaksi antara konsentrasi NAA dengan dosis 100 ppm dan Growmore menghasil muncul tunas terbaik yang lebih cepat yaitu 28,65 hari, sedangkan konsentrasi NAA dengan dosis 200 ppm dan jenis pupuk daun Growmore menghasilkan muncul tunas lebih lama yaitu 64,10 hari, hal ini mengindikasikan bahwa penggunaan konsentrasi hormon NAA dengan dosis 100 ppm dengan pupuk daun Growmore mampu memacu pertumbuhan akar.

Tabel 1. Interaksi konsentrasi hormon NAA dan jenis pupuk daun terhadap saat muncul tunas (hari)

\begin{tabular}{lc}
\hline \multicolumn{1}{c}{ Perlakuan } & Saat Muncul Tunas (hari) \\
\hline N0 P1(NAA 0 ppm, dan Growmore) & $35.43 \mathrm{ab}$ \\
N1P1(NAA 100 ppm, dan Growmore) & $28.65 \mathrm{a}$ \\
N2P1(NAA 200 ppm, dan Growmore) & $64.10 \mathrm{~b}$ \\
N3P1(NAA 300 ppm, dan Growmore) & $43.53 \mathrm{ab}$ \\
N0 P2 (NAA 0 ppm, dan Gandasil D) & $47.83 \mathrm{~b}$ \\
N1P2 (NAA 100 ppm, dan Gandasil D) & $60.43 \mathrm{~b}$ \\
N2P2 (NAA 200 ppm, dan Gandasil D) & $44.65 \mathrm{ab}$ \\
N3P2 (NAA 300 ppm, dan Gandasil D) & $59.40 \mathrm{~b}$ \\
\hline BNT 5\% & $\mathbf{1 7 . 6 4}$ \\
\hline
\end{tabular}

Keterangan : Angka yang diikuti huruf yang sama pada kolom yang sama, tidak berbeda nyata pada uji BNT 5\%. 
A. Sumiati dan Astutik/ Buana Sains Vol 19 No 2 : 13-22

Isda dan Fatonah (2014) menyatakan bahwa penambahan zat pengatur tumbuh yang sesuai dapat meningkatkan aktivitas pembelahan sel dalam proses morfogenesis dan organogenesis. Hal ini diduga pemberian NAA secara tunggal dengan konsentrasi yang cukup akan memberikan pertumbuhan akar tanaman, sehingga dapat meningkatkan pembentukan tunas yang optimal.

Pada Tabel 1, menunjukkan bahwa pupuk daun Growmore dikombinasikan dengan konsentrasi hormon NAA menghasilkan respon lebih tinggi dalam meningkatkan pertumbuhan Phalaenopsis hibrida dibandingkan dengan pupuk daun Gandasil D yang dikombinasikan dengan konsentrasi hormon NAA, hal ini diduga kandungan $\mathrm{N}$ yang tinggi pada pupuk daun Growmore dapat menyediakan unsur $\mathrm{N}$ lebih banyak dibandingkan pupuk daun Gandasil D yang memiliki kandungan N yang lebih rendah. Zasari (2015), nitrogen adalah unsur hara makro yang sangat dibutuhkan tanaman, kekurangan nitrogen akan menghambat pertumbuhan vegetatif tanaman.

\section{Pertambahan Jumlah Daun (helai)}

Tidak terdapat hasil interaksi baik konsentrasi hormon NAA maupun jenis pupuk daun terhadap pertambahan jumlah daun (helai) pada semua umur pengamatan (minggu). Konsentrasi hormon NAA secara terpisah tidak berpengaruh terhadap pertambahan jumlah daun pada semua umur pengamatan, dan jenis pupuk daun tidak berpengaruh terhadap pertambahan jumlah daun pada semua umur pengamatan. (Tabel 2). Tabel 2 menunjukkan bahwa pemberian konsentrasi NAA 0 ppm sampai 300 ppm serta jenis pupuk daun belum mampu memberikan pengaruh terhadap pertambahan jumlah daun, hal tersebut karena kemungkinan hormon secara eksogen terlalu rendah atau belum cukup untuk memacu pertumbuhan akar, sehingga menghambat pertambahan jumlah daun, diduga karena pertumbuhan tanaman seperti jumlah daun, juga dipengaruhi oleh faktor-faktorlain, seperti ketersediaan hara, air dan kondisi lingkungan.

Tabel 2. Pengaruh konsentrasi hormon NAA dan jenis pupuk daun pada pertambahan jumlah daun pada semua umur pengamatan (minggu)

\begin{tabular}{|c|c|c|c|c|}
\hline \multirow{2}{*}{$\begin{array}{l}\text { Perlakua } \\
\mathrm{n}\end{array}$} & \multicolumn{4}{|c|}{ Pertambahan Jumlah Daun (helai) Pada Umur (minggu } \\
\hline & 4 & 8 & 12 & 16 \\
\hline \multicolumn{5}{|c|}{ Konsentrasi NAA (ppm): } \\
\hline $\mathrm{N}_{0}$ (Kontrol) & 0.94 & 1.44 & 1.21 & 1.21 \\
\hline $\mathrm{N}_{1}(100 \mathrm{ppm})$ & 0.76 & 1.02 & 1.28 & 1.28 \\
\hline $\mathrm{N}_{2}(200 \mathrm{ppm})$ & 0.88 & 0.92 & 1.20 & 1.24 \\
\hline $\mathrm{N}_{3}(300 \mathrm{ppm})$ & 0.80 & 0.96 & 1.15 & 1.17 \\
\hline BNT 5\% & tn & tn & tn & tn \\
\hline \multicolumn{5}{|l|}{ Jenis Pupuk: } \\
\hline $\mathrm{P}_{1}$ (Growmore) & 0.87 & 1.15 & 1.18 & 1.20 \\
\hline $\mathrm{P}_{2}($ Gandasil D) & 0.82 & 1.02 & 1.24 & 1.24 \\
\hline BNT 5\% & tn & th & tn & tn \\
\hline
\end{tabular}

Keterangan : Angka yang diikuti huruf yang sama pada kolom yang sama, tidak berbeda nyata pada uji BNT 5\%. 
Hasil penelitian Ekosari, (2009) menunjukan bahwa jumlah daun dipengaruhi oleh genotip dan lingkungan serta pertumbuhan dan perkembangan tanaman didukung oleh berbagai faktor eksternal dan internal tanaman yang bekerja sama dalam keseimbangan yang serasi.

Tabel 2 menunjukkan bahwa pada pemberian pupuk daun Growmore dan Gandasil D tidak memberikan pengaruh yang nyata terhadap pertambahan jumlah daun. Pada fase pertumbuhan vegetatif perlu diberikan pupuk dengan kandungan $\mathrm{N}$ yang tinggi, karena unsur tersebut merupakan bahan utama untuk menyusun protein yang dibutuhkan dalam pembelahan sel (Sandra, 2001). Pada tanaman anggrek muda pemberian pupuk dengan kandungan $\mathrm{N}$ tinggi akan memberikan pertumbuhan yang lebih baik dan cepat, karena nitrogen adalah bahan utama penyusun asam amino, protein, asam nukleat, berbagai enzim dan sebagai zat penghijau daun.

Kondisi lingkungan dan jenis tanaman mempengaruhi pertumbuhan tanaman Phalaenopsis, variasi respon terhadap pemberian zat pengatur tumbuh (ZPT) dipengaruhi oleh perbedaan fase pertumbuhan, kondisi fisiologis, kemampuan tanaman mengabsorpsi ZPT. Pertambahan jumlah daun dipengaruhi oleh pemberian larutan hormon NAA dan pupuk daun yang mengandung unsur hara esensial yaitu Nitrogen $(\mathrm{N})$ yang berperan dalam pertumbuhan vegetatif tanaman Anggrek Phalaenopsis hibrida.

\section{Pertambahan Panjang Daun (cm)}

Tidak terdapat interaksi antara konsentrasi hormon NAA dengan jenis pupuk daun terhadap pertambahan panjang daun pada semua umur pengamatan (minggu), Konsentrasi hormon NAA secara terpisah berpengaruh nyata terhadap pertambahan panjang daun pada umur 12 dan 16 minggu, sedangkan jenis pupuk daun tidak berpengaruh terhadap variabel pertambahan panjang daun pada semua umur pengamatan. (Tabel 3).

Tabel 3. Pengaruh konsentrasi hormon NAA dan jenis pupuk daun pertambahan panjang daun $(\mathrm{cm})$ semua umur pengamatan (minggu)

\begin{tabular}{lcccc}
\hline Perlakuan & \multicolumn{5}{c}{ Pertambahan Panjang Daun (helai) Pada Umur } \\
\cline { 2 - 5 } & 4 & 8 & 12 & 16 \\
\hline Konsentrasi NAA (ppm) : & & & & \\
N0 (Kontrol) & 0.32 & 0.45 & $0.56 \mathrm{a}$ & $0.73 \mathrm{a}$ \\
N1 (100 ppm) & 0.34 & 0.44 & $0.55 \mathrm{a}$ & $0.71 \mathrm{a}$ \\
N2 (200 ppm) & 0.39 & 0.75 & $1.13 \mathrm{~b}$ & $1.49 \mathrm{~b}$ \\
N3 (300 ppm) & 0.26 & 0.43 & $0.48 \mathrm{a}$ & $0.70 \mathrm{a}$ \\
\hline \multicolumn{1}{c}{ BNT 5\% } & tn & tn & $\mathbf{0 . 3 8}$ & $\mathbf{0 . 4 5}$ \\
\hline Jenis Pupuk: & & & & \\
P1 (Growmore) & 0.32 & 0.51 & 0.76 & 0.97 \\
P2 (Gandasil D) & 0.33 & 0.52 & 0.60 & 0.85 \\
\hline \multicolumn{1}{c}{ BNT 5\% } & tn & tn & tn & tn \\
\hline
\end{tabular}

Keterangan : Angka yang diikuti huruf yang sama pada kolom yang sama, tidak berbeda nyata pada uji BNT 5\%. 
A. Sumiati dan Astutik/ Buana Sains Vol 19 No 2 : 13-22

Tabel 3 menunjukkan bahwa pertambahan panjang daun terus meningkat setiap umur pengamatan dengan memperlihatkan pengaruh konsentrasi hormon NAA dengan dosis 200 ppm berpengaruh sangat baik dalam merangsang pertumbuhan vegetatif tanaman Phalaenopsis hibrida, yaitu meningkatkan panjang daun sampai umur 16 minggu sebesar 1,49 $\mathrm{cm}$, hal ini disebabkan oleh kandungan hormon NAA sudah berpengaruh terhadap pertumbuhan akar, nutrisi yang diserap oleh tanaman dapat lebih baik sehingga memacu pertambahan panjang daun, sedangkan dengan konsentrasi NAA 0 ppm dan 300 ppm tidak berpengaruh terhadap pertambahan panjang daun, hal ini mengindikasikan bahwa respon suatu tanaman tanpa pemberian konsentrasi hormon dan sebaliknya apabila pemberian suatu konsentrasi terlalu tinggi tidak dapat merespon tanaman dalam menyerap nutrisi yang tersedia pada pertumbuhan dan perkembangan tanaman.

Widiastoety

menambahkan bahwa peningkatan pertumbuhan panjang daun disebabkan karena adanya percepatan pembelahan sel dan mendorong proses diferensiasi. Pembelahan sel membutuhkan energi yang diperoleh dariauksin serta nutrisi lainnya.

\section{Pertambahan Lebar Daun (cm)}

Tidak terdapat interaksi antara konsentrasi hormon NAA dengan jenis pupuk daun terhadap pertambahan pertambahan lebar daun pada semua umur pengamatan (minggu). Konsentrasi hormon NAA secara terpisah berpengaruh sangat nyata terhadap pertambahan lebar daun pada umur 8,12 dan 16 minggu, sedangkan jenis pupuk daun tidak terdapat pengaruh terhadap variabel pertambahan lebar daun pada semua umur pengamatan.

Hasil Tabel 4 menunjukkan bahwa, pertambahan lebar daun yang terbaik diperoleh pada pemberian NAA 200 ppm yaitu $1,06 \mathrm{~cm}$ sampai dengan umur 16 minggu, hal ini disebabkan oleh kandungan hormon yang masih tersedia dalam pembentukan akar dalam memacu perkembangan tanaman. hormon NAA secara terpisah berpengaruh sangat nyata terhadap pertambahan lebar daun pada umur 8, 12 dan 16 minggu, sedangkan jenis pupuk daun tidak terdapat pengaruh terhadap variabel pertambahan lebar daun pada semua umur pengamatan.

Hasil Tabel 4 menunjukkan bahwa, pertambahan lebar daun yang terbaik diperoleh pada pemberian NAA 200 ppm yaitu $1,06 \mathrm{~cm}$ sampai dengan umur 16 minggu, hal ini disebabkan oleh kandungan hormon yang masih tersedia dalam pembentukan akar dalam memacu perkembangan tanaman, hal ini dimungkinkan kandungan hormon NAA dapat berpengaruh terhadap pertumbuhan akar sehingga dapat memberikan pertambahan lebar daun Hasil penelitian Surur, (2016) menunjukan bahwa pemberian pupuk daun Gandasil D dan Growmore memperoleh hasil yang lebih baik pada pupuk daun Growmore dengan konsentrasi $3 \mathrm{~g} / \mathrm{l}$ berpengaruh yang sama terhadap panjang daun pada pemberian Growmore dengan konsentrasi $1 \mathrm{~g} / \mathrm{l}$ dan $2 \mathrm{~g} / \mathrm{l}$. Widiastoety (2014) menyatakan bahwa panjang dan lebar daun erat hubungannya dengan arah pembelahan, pembesaran, jumlah, dan distribusi sel. Makin luas daun, jumlah stomata semakin bertambah. Stomata sangat berperan dalam penyerapan nurisi 
A. Sumiati dan Astutik/ Buana Sains Vol 19 No $2: 13-22$

Tabel 4. Pengaruh konsentrasi hormon NAA dan jenis pupuk daun terhadap pertambahan lebar daun (cm) pada semua umur pengamatan (minggu)

\begin{tabular}{|c|c|c|c|c|}
\hline Perlakuan & 4 & 8 & 12 & 16 \\
\hline \multicolumn{5}{|c|}{ Konsentrasi NAA (ppm): } \\
\hline NO (Kontrol) & 0.74 & $0.83 \mathrm{a}$ & $0.87 \mathrm{a}$ & $0.91 \mathrm{a}$ \\
\hline N1 (100 ppm) & 0.77 & $0.80 \mathrm{a}$ & $0.86 \mathrm{a}$ & $0.90 \mathrm{a}$ \\
\hline N2 (200 ppm) & 0.80 & $0.96 \mathrm{~b}$ & $1.00 \mathrm{~b}$ & $1.06 \mathrm{~b}$ \\
\hline N3 (300 ppm) & 0.90 & $0.80 \mathrm{a}$ & $0.85 \mathrm{a}$ & $0.92 \mathrm{a}$ \\
\hline BNT 5\% & tn & 0.09 & 0.10 & 0.10 \\
\hline \multicolumn{5}{|l|}{ Jenis Pupuk: } \\
\hline P1 (Growmore) & 0.76 & 0.85 & 0.89 & 0.94 \\
\hline P2 (Gandasil D) & 0.84 & 0.84 & 0.90 & 0.95 \\
\hline BNT 5\% & tn & tn & tn & tn \\
\hline
\end{tabular}

Keterangan : Angka yang diikuti huruf yang sama pada kolom yang sama, tidak berbeda nyata pada uji BNT 5\%.

Tabel 5. Konsentrasi hormon NAA dan pupuk daun terhadap presentase tanaman hidup (\%)

\begin{tabular}{|c|c|c|}
\hline & Perlakuan & Presentase Tanaman Hidup $(\%)$ \\
\hline N0 P1 & (NAA 0 ppm, dan Growmore) & $83,33 a$ \\
\hline N1 P1 & (NAA 100 ppm, dan Growmore) & $100,00 \mathrm{a}$ \\
\hline N2 P1 & (NAA 200 ppm, dan Growmore) & 83,33 a \\
\hline N3 P1 & (NAA 300 ppm, dan Growmore) & $75,00 \mathrm{a}$ \\
\hline No P2 & (NAA 0 ppm, dan Gandasil D) & $100,00 \mathrm{a}$ \\
\hline N1 P2 & (NAA 100 ppm, dan Gandasil D) & $91,67 \mathrm{a}$ \\
\hline N2 P2 & (NAA 200 ppm, dan Gandasil D) & $100,00 \mathrm{a}$ \\
\hline N3 P2 & (NAA 300 ppm, dan Gandasil D) & $100,00 \mathrm{a}$ \\
\hline \multicolumn{2}{|r|}{ BNT 5\% } & tn \\
\hline
\end{tabular}

Keterangan : Angka yang diikuti huruf yang sama pada kolom yang sama, tidak berbeda nyata pada uji BNT 5\%.

\section{Presentase Tanaman Hidup (\%)}

Pemberian konsentrasi hormon NAA dan jenis pupuk daun terhadap presentase tanaman hidup tidak terdapat interaksi. Tabel 5, menunjukkan bahwa persentase pertumbuhan tanaman Anggrek Phalaenopsis hibrida mencapai 91,67\%. Hasil presentase tanaman hidup yang paling baik diperoleh pada perlakuan $\mathrm{N}_{1} \mathrm{P}_{1}, \mathrm{~N}_{0} \mathrm{P}_{2}, \mathrm{~N}_{2} \mathrm{P}_{2}$, dan $\mathrm{N}_{3} \mathrm{P}_{2}$ dengan memperoleh presentase tanaman hidup masing-masing sebesar 100,00\%, dan hasil presentase hidup terendah diperoleh pada pemberian $\mathrm{N}_{3} \mathrm{P}_{1}$ dengan mempeoleh hasil sebesar 75,00\%, Penurunan persentase tumbuh diduga karena suhu di dalam green bouse yang cukup tinggi dikarenakan musim kemarau yang berkepanjangan. Tingginya suhu pada musim kemarau menyebabkan tanaman anggrek Phalaenopsis amabilis pertumbuhannya tidak optimum. Menurut Iswanto (2010) ciri-ciri akar anggrek yang sehat adalah akar anggrek yang memiliki struktur akar keras (tidak lembek), berwarna hijau dengan ujung 
A. Sumiati dan Astutik/ Buana Sains Vol 19 No 2 : 13-22

akar berwarna ungu atau hijau kekuningan, hingga berwarna hijau. Persentase tumbuh tanaman juga dipengaruhi oleh kondisi akar tanaman anggrek Phalaenopsis amabilis yang mengalami kerusakan. Kerusakan tersebut kemungkinan disebabkan oleh kurangnya kelembaban media dan udara sehingga akar menjadi kering yang ditunjukkan oleh akar yang mengerut dan kering. Respon pertumbuhan tanaman Anggrek Phalaenopsis hibrida hasil budidaya berdasarkan parameter saat muncul tunas, jumlah daun, panjang daun, lebar daun dan persentase tanaman hidup menunjukkan hasil yang baik. Persentase tanaman mati tertinggi ditunjukkan pada pemberian konsentrasi hormon NAA 300 ppm dan pupuk daun Growmore $\left(\mathrm{N}_{3} \mathrm{P}_{1}\right)$.

\section{Kesimpulan}

Terdapat interaksi antara konsentrasi NAA dan jenis pupuk daun terhadap saat muncul tunas. Saat muncul tunas tercepat pada perlakuan NAA 100 ppm, dan pupuk Growmore $\left(\mathrm{N}_{1} \mathrm{P}_{1}\right)$, yaitu 29 hari namun tidak berbeda dengan $\left(\mathrm{N}_{0} \mathrm{P}_{1}\right),\left(\mathrm{N}_{3} \mathrm{P}_{1}\right),\left(\mathrm{N}_{2} \mathrm{P}_{2}\right)$. Secara terpisah konsentrasi hormon NAA berpengaruh terhadap pertambahan panjang daun umur 12-16 minggu dan pertambahan lebar daun sampai umur 8-16 minggu. Pertumbuhan Phalaenopsis hibrida terbaik diperoleh pada pemberian NAA 200 ppm dengan pertambahan panjang daun $1,49 \mathrm{~cm}$ dan pertambahan lebar daun $1,06 \mathrm{~cm}$ sampai dengan umur 16 minggu.

\section{Daftar Pustaka}

Astutik. 2006. Uji Berbagai Media Pada Aklimatisasi Hibrida Denrobium. J. Buan Sains. Vol. 6, No. 1:89- 92.
Astuti, dan H.P. Devi. 2011. Induksi Pembelahan Sporofitik Mikrospora Anggrek Bulan (Phalaenopsis ambilis). Skripsi. Perpustakaan Universitas Airlangga.

Burhan, B. 2016. Pengaruh Jenis Pupuk dan Konsentrasi Benzyladenin (BA) Terhadap Pertumbuhan dan Pembungaan Anggrek Dendrobium Hibrida. J. Penelitian Pertanian Terapan. Vol. 16, No. 3:194-204.

Ekosari, A. 2009. Pengaruh Ga3 Dan Iaa Terhadap Pembesaran Bonggol Adenium (Adenium obesum). Skripsi. FP. Universitas Sebelas MaretSurakarta.

Ginting B., 2008. Membuat media tumbuh anggrek. KP Penelitian Tanaman Hias, Deptan.

Hayuning. M.L.A., E.E. Nurlaelih., dan

T. Wardiyati. 2011. Aplikasi Zat Pengatur Tumbuh Dalam Induksi Pembungaan Anggrek Bulan (Phalaenopsis sp.). J. Buana Sains. Vol. 11, No. 2:119126.

Isda, M.N, dan S. Fatonah. 2014. Induksi Akar Pada Eksplan Tunas Anggrek Grammatophylu Scriptum Var. Citrinum Secara In Vitro Pada Media MSdengan Penambahan NAA dan BAP. J. Biologi.Vol. 7, No. 2:53-57.

Iswanto, H. 2001. Anggrek Phalaenopsis. Agro Media Pustaka. Jakarta. 
A. Sumiati dan Astutik/ Buana Sains Vol 19 No 2 : 13-22

Lisnandar, D.S., W. Mudyantini, dan A. Pitoyo. 2012. Pengaruh pemberian variasi konsentrasi NAA $\quad(\alpha$-naphthaleneacetic acid) dan $2.4 \mathrm{D}$ terhadap induksi protocorm like bodies (PLB) anggrek macan (Grammatophyllum scriptum (Lindl.). BioteknologiVol.9, No. 2:66-72.

Nisak. K., T. Nurhidayati, K. I. Purwani. 2012. Pengaruh Kombinasi konsentrasi ZPT NAA dan BAP Kultur Jaringan Tembakau Nicotiana tabacum var. Prancak 95. J. Sains Dan Seni Pomits. Vol. 1, No. 1:1-6.

Sandra, E., 2001. Membuat anggrek Rajin Berbunga. Agromedia Pustaka, Jakarta.

Suradinata, Y. R., A. Nuraini, dan A. Setiadi. 2012. Pengaruh Kombinasi Media Tanam Dan Konsentrasi Pupuk Daun Terhadap Pertumbuhan Tanaman Anggrek Dendrobium Sp. Pada Tahap Aklimatisasi. J. Agrivigor.Vol. 11. No. 2:104 -116.

Surur, M.M. 2016. Pengaruh Pemberian Pupuk Daun Gandasil D Dan Growmore Dengan Teknologi Nano Terhadap Pertumbuhan Vegetatif Anggrek Dendrobium sp. Pada Tahap Aklimatisasi. Artikel Skripsi Universitas Nusantara PGRI Kediri.

Untari, R., D.M. Puspitaningtyas.2006. Pengaruh Bahan Organik dan NAA terhadap Pertumbuhan Anggrek Hitam (Coelogyne pandurata Lindl.) dalam Kultur in Vitro. J. Biodiversitas. Vol. 7, No. 3:344-348.
Widiastoety, D. 2014. Pengaru6h Auksin dan Sitokinin Terhadap PertumbuhanPlanlet Anggrek Mokara. J. Hort. Vol. 24, No. 3:230-238. 
A. Sumiati dan Astutik/ Buana Sains Vol 19 No 2 : 13-22 